\title{
Ecosystem Services as a Promising Paradigm to Protect Environmental Rights of Indigenous Peoples in Latin America: the Constitutional Court Landmark Decision to Protect Arroyo Bruno in Colombia
}

\author{
Luisa Gómez-Betancur ${ }^{1} \cdot$ Sandra P. Vilardy Q. (10 ${ }^{2} \cdot$ David Torres R. ${ }^{3}$ \\ Received: 2 December 2020 / Accepted: 4 May 2021 / Published online: 24 May 2021 \\ (c) The Author(s), under exclusive licence to Springer Science+Business Media, LLC, part of Springer Nature 2021
}

\begin{abstract}
In the last years, the interest in ecosystem services (ESs) as a decision-making tool for environmental policy has been growing. The ES paradigm has also impacted the judicial system and in some countries the common law tradition. Experiences and lessons learned from the ES litigation have been already documented. In the initial analysis, this article aims to identify key trends in ESs case law in Latin America - a leading region in environmental constitutionalism-by exploring the judicial decisions issued by high courts and subnational environmental courts that mention or incorporate the ES term. In the second level of analysis, we focused on the Colombian Constitutional Court landmark decision; the Arroyo Bruno judgment aimed to protect the rights to water, food security, and health of the Wayuú indigenous people. We argue this is a groundbreaking ruling in Latin America, given that for the first time, a Court uses the ES-based approach to protect the environmental rights of ethnic communities, incorporating ES concepts to the constitutional law sphere and integrating into the same conversation, interdisciplinary and intercultural knowledge.
\end{abstract}

Keywords Ecosystem services $\cdot$ Environmental constitutionalism $\cdot$ Human rights $\cdot$ Indigenous peoples $\cdot$ Latin America $\cdot$ Colombia

\section{Introduction}

In the last three decades, constitutions worldwide have addressed environmental matters in a persistent and pervasive manner (Daly et al. 2017). This trend has been accompanied by a leading role of judicial institutions that have issued extraordinary decisions to protect the environment, even where constitutions neither explicitly mention the right to a healthy environment nor embrace the rights to nature.

This growing phenomenon that embodies to "extend constitutionalism into the environmental domain" (Daly et al. 2017) is known as environmental constitutionalism. It

Sandra P. Vilardy Q.

s.vilardy@uniandes.edu.co

International Criminal Court, The Hague, The Netherlands

2 School of Management, Universidad de Los Andes, Bogotá, Colombia

3 Clínica Jurídica de Medio Ambiente y Salubridad Pública, Universidad de Los Andes, Bogotá, Colombia encompasses the recognition that the environment is subject to protection and vindication by constitutional provisions, processes, and institutions, in particular, judges (May and Daly 2014). Specialized constitutional courts, environmental tribunals, and other diffuse judicial review systems at national and subnational levels (May and Daly 2017) have increasingly engaged in vindicating rights in a broad range of settings, from biodiversity loss to water and air pollution to the climate crisis.

Nonetheless, these approaches to vindicate environmental human rights by courts have not been adopted worldwide. In each country and region, the judiciary has adjudicated environmental constitutionalism through varying perspectives. In some jurisdictions, despite the existence of constitutional provisions purporting to advance substantive environmental rights, these have laid dormant, and reluctance to engage with these rights by domestic tribunals has been the rule. For example, despite the constitutional right to enjoy a suitable environment is protected in Spain, courts have held it falls outside the actionable private "rights" (May and Daly 2019), and it is enforceable only when an ombudsman initiates litigation (May and Daly 2014). 
Other tribunals, however, have been more activist and have adopted an approach recognizing constitutional provisions that expressly embody independent environmental rights. Constitutional and apex courts have upheld but also enforced the right to a healthy, balanced, quality, or benevolent environment. Although not exclusively, most of these case laws emanate from courts in South America and Central Europe. One of the earliest case in which a court recognized the constitutional right to a healthy environment is the Trillium decision in 1997 (Chilean Supreme Court of Justice, 2.732-96 1998). By establishing the conditions under which the "Rio Condor Project" should be executed by the Trillium Corporation and the Chilean government, the Supreme Court of Chile protected the right of Chilean citizens to live in an environment free from contamination and held that this right owed to all citizens, even though none of them had personally suffered any injury. In early cases, other courts of the region have also held the right to a healthy and balanced environment as fundamental, selfexecuting, and enforceable by any citizen. ${ }^{1}$ As early as in Latin America, in Central and Eastern European countries, constitutional courts also recognized and implemented the right to a healthy and benevolent environment. Among others, this has been the case of the Constitutional Court of Hungary (Constitutional Court, 28/1994 1994) and Constitutional Court of Latvia (Constitutional Court, 2008-3803 2009).

Within the range of the mentioned categories of judicial receptivity to environmental constitutionalism-the dormant and independent environmental rights - there are at least two other judicial approaches that have been identified. Domestic tribunals have also recognized environmental rights as an adjunct to the constitutional directives concerning environmental governance. The abovementioned means that substantive environmental rights depend on the existence of an environmental policy or duty (May and Daly 2019). ${ }^{2}$ In addition, several courts

\footnotetext{
${ }^{1}$ In the Ruling 3705-93 (Constitutional Court of Costa Rica 1993), the Constitutional Court of Costa Rica held that a healthy and ecologically balanced environment is a fundamental right, self-executing and enforceable by any citizen. The same year, the First Chamber of Appeal of La Plata Argentina, in Ruling 232.609 (First Chamber of Appeal of La Plata Argentina 2006), found enforceable the right to live in a healthy and balanced environment.

${ }^{2}$ In the Juan Antonio Oposa et al. v. The Honorable Fulgencio S. Factoran case (Supreme Court of Philippines 1993), the Supreme Court of the Philippines stated that rights to a quality environment were enforceable despite the constitution not explicitly recognizing them. Based on a constitutional directive that "[t]he State shall protect and advance the right of the people to a balanced and healthful ecology in accord with the rhythm and harmony of nature," the Court found that even if balanced and healthful ecology had not been drafted as a right, it was mandated as State policy by the Constitution itself, thereby underlining their critical importance and imposing upon the State an obligation to preserve and protect.
}

worldwide have stated that environmental rights are implicitly incorporated into other substantive and enforceable rights. In consequence, the right to a healthy and balanced environment has been recognized through the protection of other constitutional rights. Courts in India ${ }^{3}$ and $\mathrm{Nepal}^{4}$ have been particularly willing to construe environmental rights from the right to life. In South America, likewise, the Constitutional Court of Colombia (Constitutional Court, T-415/92 1992; Constitutional Court, T-095/97 1997; Constitutional Court, T-220/95 1995) and the Supreme Court in Chile (Supreme Court of Chile, Comunidad de Chanaral v. Codeco División el Saldor) have demonstrated promising ways to vindicate substantive environmental rights following this same approach.

Lately, different perspectives to protect nature have been emerging within constitutionalism. It is the case of the rights to nature, a framework that aligns with environmental philosophies such as deep ecology and other biocentric approaches that react critically to that modern anthropocentric perspective (UN General Assembly 2014). Examples of this approach are the cases involving the Amazon rainforest and the Atrato River in Colombia, in which the Supreme and the Constitutional Courts, respectively, protected, besides the population affected, the river and the forest as ecosystems "subject of rights". Indeed, the judicial reasoning in these cases has echoed in other domestic judges, who have also recognized as subjects of law more rivers, national parks, and different ecosystems - such as moorlands (páramos). These cases have triggered the latest debates about how this biocentric approach can strengthen environmental constitutionalism to protect both humans and nonhumans (Goméz-Betancur 2020).

According to two recent major works on environmental constitutionalism-The Environmental Rights Revolution (Boyd 2012) and Global Environmental Constitutionalism (May and Daly 2014) — the commitment to opening the courthouse doors to environmental claimants has been well established in countries in Southeast Asia and Latin America (Boyd 2011; May and Daly 2009, 2014). In the latter region, the overwhelming majority of the countries have enshrined environmental rights in their constitutions or provided detailed provisions to flesh out these rights and the reciprocal government duties (Boyd 2012). This is not

\footnotetext{
${ }^{3}$ In cases such as Subhash Kumar v. State of Bihar, M.C. Mehta v. Union of India, and Charan Lal Sahu v. Union of India (Supreme Court of India 1991), the Supreme Court of India has found that the right to life embeds a right to a quality environment.

${ }^{4}$ In the case of Advocate Prakash Mani Sharma and others v. Godavari Marble Industries Pvt. Ltd. and others, (the Nepalese Supreme Court 2016) has held that since a healthy environment is indispensable for human life, it is embedded within the domains of the right to life.
} 
to say that environmental constitutionalism is monolithic in Latin America. The approaches to judicially enforceable environmental rights vary from country to country and rely deeply on the type of constitution and its ideology, ranging from liberal to more radical constitutions ${ }^{5}$. Across this constitutional experience in Latin America is where some of the world's most innovative and energetic approaches to environmental constitutionalism have been identified (Daly and May 2018).

The constitutionalization of environmental rights in this region has been developed in a context where high biological diversity and intense resource extraction pressure are coexistent phenomena. Latin America is one of the highest biologically and culturally diverse regions in the world. "It hosts 7 out of the 17 most biodiverse countries of the world and spans from pole to pole, with some of the most extensive wilderness areas on the planet and highly distinctive or irreplaceable species composition" (Rice et al. 2018a, 2018b). Together with the Caribbean countries, Latin America "supports with around sixty percent of global terrestrial life found within it, alongside diverse freshwater and marine flora and fauna. [This] region's biomes extend from wetlands and coastal ecosystems to deserts, tropical forests, extensive savannah grasslands, and high altitude Andean habitats. The lowland forests are amongst the most species-rich on Earth, and the mountain forests and moorlands (páramos) of the Andes host a wide range of endemic and narrow range species. This regional diversity is driven by a number of environmental factors, including a complex evolutionary history and highly variable geography, geology and climate" (UNEP-WCMC 2016)

Simultaneously, the countries in this region face a high prevalence of social conflicts around environmental issues. According to the Environmental Justice Atlas, at least $31.08 \%$ of the global conflicts currently exist in the Caribbean, Meso, and South Americas. Among the five first countries with significant rates of socio-environmental conflict are Brazil and Colombia.

In this regional scenario, both access to justice for citizens and communities through simplified and low-cost "writ of protection" procedures and bold judicial decisions have paved the way for developing environmental constitutionalism in Latin America (Collins 2017). However, the justiciability of environmental rights does not escape

\footnotetext{
5 According to Daniel Bonilla (2019), liberal constitutions in Latin America are based on modern constitutionalism grammar-which is composed by rules and meanings created by famous philosophers such as Hobbes and Locke-and their approach to environmental issues separate from the multicultural ones. On the other hand, radical constitutions differ from liberal constitutions, as they articulate a new political movement built around their local experiences-particularly the indigenous one-thus relating nature and human beings in a direct manner.
}

from challenges. Constitutional courts and environmental tribunals continually face difficult questions about the manner to fully assess how our impacts on nature, either degrading or restoring, are affecting human well-being. Also, they deal with matters such as how to provide a more comprehensive understanding of the benefits, trade-offs, and consequences of human actions over nature (Sharon et al. 2018). While the resource-driven economic system is pervasive in Latin America (Carvajal 2016) and vulnerable groups increasingly demand justice (Svampa 2012), domestic judges are called to deal with the urgency of advancing social and environmental justice through creative, interdisciplinary, and meaningful tools.

The recognition of the ecosystem services (ESs) paradigm in the decision-making process for environmental policy is growing. ${ }^{6}$ Interestingly, its use by judicial systems as a tool to fully understand and assess human actions seems to follow this fashion. Emerging trends and relevant lessons that inform the ES litigation have already been studied in some countries with common law tradition (Sharon et al. 2018).

This study aims to identify trends in ecosystem case law in Latin America, a leading region in environmental constitutionalism, and contributions that ESs based approach may bring to protect environmental rights through judicial decisions in the regional context. Specifically, we propose to analyze the Constitutional Court landmark decision to protect Arroyo Bruno in Colombia and frame it as a promising case to safeguard indigenous peoples' human rights in regions particularly vulnerable to the climate crisis.

\section{Methods}

This research focused on the judicial decisions issued by high courts and subnational environmental courts of Latin American countries that mention or incorporate the ES term. We decided to develop an analysis on two different levels. The first level aims to examine the judgments in 16 Latin American countries in which the ES paradigm has been mentioned or enforced (Colombia, Mexico, Argentina, Chile, Peru, Uruguay, Paraguay, Venezuela, Panama, El Salvador, Puerto Rico, Dominican Republic, Guatemala,

\footnotetext{
${ }^{6}$ The Millennium Ecosystem Assessment (2003) set up a conceptual framework to link the contributions of biodiversity and human wellbeing. These links are well known as ES, and they are paramount to advance in recognition of society's dependence on the functioning of ecosystems. The new framework of Intergovernmental Science-Policy Platform on Biodiversity and Ecosystem Services-IPBES-(Rice et al. 2018a, 2018b) proposes further developments by recognizing the contributions of nature to people - an approach that includes analogous concepts to ecosystem services and integrates multiple cultural visions. This framework also clarifies that many of nature's contributions are not entirely replaceable and some are irreplaceable.
} 
Honduras, Costa Rica, and Cuba) ${ }^{7}$. The second level of analysis discusses Arroyo Bruno's case (SU-698/2017, 2017), framing it as a landmark decision regarding ESs in Latin America.

We decided to guide the research based on two considerations. First, the fact that the countries chosen are from the Global South, in particular, Latin America, and share common constitutional features ${ }^{8}$. Also, the region converges on experiences related to the struggle for environmental justice. Legal scholars have considered that the judicial systems of the Global South are composed of derivatives of major legal traditions of the world, the effectiveness of the law in the Global South is generally very low, and the application of the law is exceptionally formal (Bonilla 2012). However, it is evidenced that the Global South has indeed formulated rich and valuable rules, theories, and doctrines, especially in environmental litigation. According to Setzer and Benjamin (2020), the Global South countries have developed a specific and valuable approach to climate litigation, as the courts have connected the climate issues to broader disputes over constitutional rights, environmental protection, land use, disaster management, and natural resource conservation.

\footnotetext{
${ }^{7}$ Deliberately, we have excluded Ecuador and Bolivia from the analysis as their approach to environmental constitutionalism differs from the rest of Latin America. The constitutions of both countries step aside from the modern constitutional models, prioritize the values of their cultural ancestry (Iacovino 2020), and introduce a biocentric approach to the relationship between human beings and nature. This approach challenges the human exceptionalism model and classical Western dualism between society and nature. In other words, it conflicts with the anthropocentric viewpoint entrenched in modern constitutionalism. Despite the transformation of the ES concept in the last years to a much broader notion of nature's contributions to people, the ES is still framed in an anthropocentric paradigm and shares substantial links. Although nature's contributions to people have increasingly recognized the diversity and complex relations between people and nature, this does not necessarily fall under a biocentric perspective or the recognition of the rights to nature. Considering that one of the pillars of the Ecuadorian and Bolivian Constitutions is the biocentric approach, and the ES paradigm does not pertain to its domains, the results of the searching in these countries might have resulted in bias. Environmental protection under radical constitutionalism in Ecuador and Bolivia deserves a separate study and different lenses to examine.

${ }^{8}$ As detailed in the article "Environmental radical constitutionalism and cultural diversity in Latin America: the rights of nature and good living in Ecuador and Bolivia" (2019), the liberal constitutions of Latin America share the following common features: (1) They employ the modern constitutionalism grammar; (2) they revolve around the principles of separation of powers, universal suffrage, and supremacy of the constitution; (3) the protection of individual rights is essential to the political ends of the nation; (4) they have expanded their bill of rights, as the constitutions include social, economic, and cultural rights; (5) they recognize the multicultural character of the society, implementing certain rights to ethnic minorities, such as the right to self-government and participation, and (6) it does not challenge modern anthropocentrism and relationship between human beings and nature is therefore vertical: people dominate over nature.
}

Second, we considered that the professional familiarity we have with the legal system and policy-making experience in Latin American countries was relevant for an effective analysis of the results. The judicial system is based on civil law tradition, and two of the authors are legally trained on it. At the same time, the third one has extensive experience as an environmental expert before the government and courts. In this category, we also consider language advantage for accessing case law through legal databases. Spanish is our mother tongue, and just as for the courts in the 18 countries examined, it is one of our working languages.

Along with this decision, the authors used two different search methods to gather a considerate sample of decisions:

The first one-which serves to gather information for the first level of analysis-consists of using the search engine Vlex. This platform collects the most relevant judgments made in Latin American countries. The authors used the keywords "Servicios Ecosistémicos" and "Contribuciones de la Naturaleza" and searched for 18 countries.

The second search method-which aims to find the legal decisions of the second level of analysis-involves the specific databases of the High Courts of Colombia in which the keywords "Servicios Ecosistémicos" and "Contribuciones de la Naturaleza" were used.

Using those methods, we found the Colombian Constitutional Court landmark decision of Arroyo Bruno's protection based on the ES paradigm.

To determine the extent to which Latin American courts have used the term ES in their decisions, and also to have a proper framework to analyze, we propose the following categorization of the judicial decisions:

The first classification corresponds to the country where the rulings were issued. It explores where the ES paradigm has been emerging or developing and monitors trends in the region.

The second category corresponds to the year in which the judgments were issued. This classification seeks to identify the regularity with which the ES term has been used or mentioned by the Latin American courts and monitor trends based on the time variable.

The third category is based on the methodology proposed by Sharon et al. (2018), in which the authors classify the use of ES in "Peripheral Mentions" or "Central issues." On the one hand, "Peripheral Mentions" are judicial decisions in which the keywords are found in the case; however, the ES concept is not central to the arguments or the ruling in the case, as they serve to contextualize the central themes (Sharon et al. 2018). On the other hand, the "Central Issue" are judgments that incorporate the ES to an extent to which the concept serves as the court ruling's foundation.

The fourth one aims to identify the scope of the mention that Latin American courts made regarding ES in their 
Fig. 1 Judicial decisions with ecosystem services mentions in Latin American countries



decisions. Thus, the authors propose determining when the courts (1) recognize the benefits of ESs; (2) provide conceptual development of ES; and (3) which aim the paradigm was used for (standard of evidence, to establish environmental impact, or define environmental restoration). We decided to limit the study of this category to the rulings in which the ES paradigm is central to the decision because we intended to focus on the meaningful use of the concept by judges.

The fifth category serves to determine if the ES debate is brought to discussion by the claimant or defendant or if the judge is the one that proposes the concept. This classification helps to identify if counterparts ask judges to use the ES term, or the concept is brought on the court's initiative, meaning a sort of judicial activism.

The sixth criteria seek to identify if the concept is used to protect ethnic (indigenous) communities' rights. This category is relevant, not only because approximately $7.8 \%$ of the Latin American population is indigenous (Congressional Research Service 2020), but is also evidenced that indigenous people are more vulnerable to the effects of the climate crisis, being affected in their ways of life, the viability of their livelihoods and eroding their traditional cultures (Kronik and Verner 2010). In addition, "although everyone depends on ESs, some people depend on them more closely than others" (UN General Assembly 2017). It is the case of indigenous peoples, who rely directly on many ecosystems' benefits for their food, fuel, and medicine. This is why "environmental harm can and often does have disastrous consequences [for them]" (UN General Assembly 2017). Understanding this context of vulnerability, the authors became interested in verifying if the plaintiffs were part of an indigenous group or if the decision was adopted to protect one of these communities.

The seventh criteria consist of identifying the type of ESs mentioned in the cases and their disaggregated benefits. This document uses the classification provided in the Update on the classification of nature's contributions to people by the Intergovernmental Science-Policy Platform on Biodiversity and Ecosystem Services (IPBES 2017) which, even though changes the denomination of ES to nature's contributions to people, divides ESs in:

(1) Regulating contributions-these services refer to functional and structural aspects of the ecosystem that modify environmental conditions experienced by people and regulate the generation of material and nonmaterial benefits (regulating ESs).

(2) Material contributions-on the other hand, material contributions are composed of substances, objects, or other material elements from nature that support communities' existence (provisioning ESs).

(3) Nonmaterial contributions-the last category includes nature's contributions to intangible aspects of human life, such as psychological quality of life and cultural relations to nature (cultural ESs).

The final criteria aims to identify which is the ecosystem provider, and as the previous categorization are both based on the rulings in which the ES paradigm is central to the decision.

\section{The First Level of Analysis: ESs in the Latin American Courts}

Eight years ago, in 2012, the first ES reference was made. Since then, this term has been gaining recognition in Latin America, showing a rising trend that peaks in 2019, depicted in Fig. 1. Though there is no complete set of the 2020 data, and considering the abnormal worldwide situation of this year, this particular year's information may prove to be an outlier in future revisions (COVID-19). Moreover, it was found that just a third of the countries in this analysis, namely, Argentina, Chile, Colombia, Costa Rica, Dominican Republic, and Mexico, have mentioned the ES term. The majority of the references come from two of these countries, Chile and Colombia, contributing 46 and $34 \%$ of the totality of judicial rulings analyzed, respectively. 
Not all ES mentions in decisions are created equal. In this study, two main distinctions are made regarding these mentions, Peripheral and Central. Mentions are considered Peripheral when keywords were found in judicial decisions, but they were not central to the arguments or judicial reasoning made in the case. In most cases, they serve to contextualize the main themes. For example, in a Mexico Supreme Court's decision, the term is brought to say that human settlements in a high environmental value zone and considered as "Conservation Soils" could provoke "... the loss of ecosystem services". However, this is just an incidental mention. Moreover, in this category also fell several cases from the environmental courts in Chile in which judges cite previous judicial theories about which hypothesis amounts to environmental damage. In these Chilean rulings, courts mention that affecting an ES could be considered as environmental damage. But, again, this is just a peripheral indication without crucial implications for the decision. More than half of the mentions are Peripheral.

The remaining mentions considered in the analysis are Central, which means that the ES concept serves as the court ruling's foundation. In this portion of decisions, there were three main aims the paradigm was used for. First, as a standard of evidence to demonstrate environmental damage. In other words, if there is damage or erosion over a particular ecosystem that hampers it to provide services, this is deemed as environmental damage. Several cases in Chile fall under this category (59\% of the Central mentions cases), as the Environmental Tribunal (South Zone) has developed a reasoning, since 2016, in which the harm to ESs is enough to prove an environmental damage. Second, at least five cases among tribunals in the Dominican Republic, Chile, and Colombia used the ES concept to establish the environmental impact of the particular anthropic intervention. As detailed in the Ruling number TC/1067 of September 17, 2013, the Constitutional Tribunal of the Dominican Republic evidenced that the exploration and exploitation of mineral deposits made by the defendant risked the ESs that Loma Miranda provides. It amounts to $33 \%$ of the cases in Central mentions. Third, in $8 \%$ of the cases, tribunals brought a Central mention of the ES term as an element to define measures for environmental restoration. An example of this situation is the Judgment R25 of September 19, 2016 issued by the Environmental Tribunal of Chile (South Zone). In this case, the Tribunal declared that the decree issued by the Ministry of Environment to protect the water of the Valdivia river basin was null, as it did not incorporate an analysis of the ES to define the measures needed to restore the environment.

Rulings with Central mentions benefited different ecosystem providers, as depicted in Fig. 2. Rivers, forests, and coastal ecosystems attract most of the attention in the claims, leaving mountains, wetlands, lakes, and other

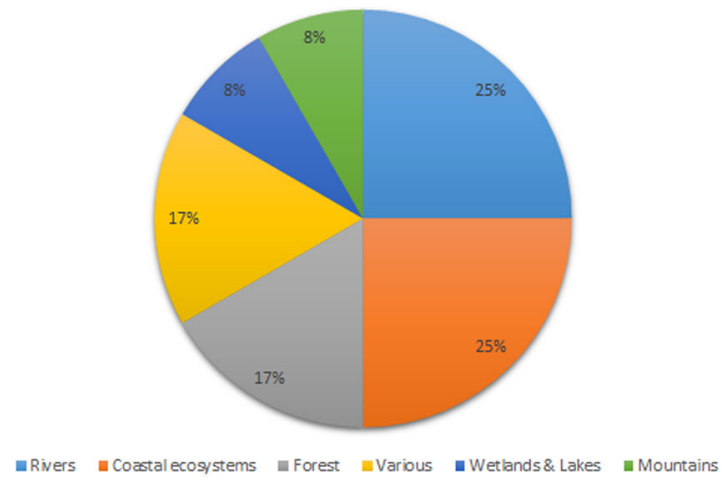

Fig. 2 Ecosystems providers in judicial decisions with central mentions of ecosystem services

ecosystems sharing the remaining third of mentions. In Chile $^{9}$ and Argentina ${ }^{10}$, the tendency of the claims is to protect aquatic ecosystems, conversely, in Colombia there is not a tendency of which ecosystems attracts most of the attention of the applicants, as the cases vary from the protection of Mountains (State of Council, 15001-23-33-0002014-00223-02(AP)), rivers (Constitutional Court, SU-698/ 17), lakes (State of Council 15001-23-33-000-2013-0035402(AP)), coastal ecosystems (State of Council 25000-2324-000-2012-00078-01 (AP)), and forests (State of Council 85001-23-31-001-2012-00044-00).

Furthermore, the claims were heavily directed to the Regulation category of ES, where the Habitat and Nutrient Cycle were seen of high value (Fig. 3). Surprisingly, the supply of water and food was regarded to a much lesser extent. Close to one-third of the claims fall under an uncategorized umbrella in which ES mentions, in spite of being Central, are still vague to be part of a classification. The mentions that did not fall under Peripheral or Central were not taken into consideration as the references were fortuitous.

The ES debate is brought to discussion by either the claimant, defendant, or the judge as shown on the left chart of Fig. 4. This classification helps to identify whether counterparts ask judges to use the ES term or the concept is brought on courts initiative which may imply some sort of judicial activism. In addition, the right chart of the same figure depicts from the data gathered whether plaintiffs were brought to the courts by an ethnic group or if the decision was adopted to protect one of these communities, showing that in these claims the communities had little influence.

\footnotetext{
${ }^{9}$ In Chile, the aquatic ecosystems are subjects of lawsuit in the following cases: R 40-2014; D 30-2017; D 3-2014; D 7-2015; D 20 2016; D 17-2016.

${ }^{10}$ In the Rulings CSJ 85/2006 and CSJ 243/2014, the Supreme Court of Argentina studied the protection of the Lake "del Diamante" and the watershed of the Atuel River, respectively.
} 
Fig. 3 Ecosystem services in central mention at judicial decisions

Fig. 4 Actors in judicial decisions. a Counterparts use the ES paradigm in judicial decisions. b Ethnic communities and ecosystem services

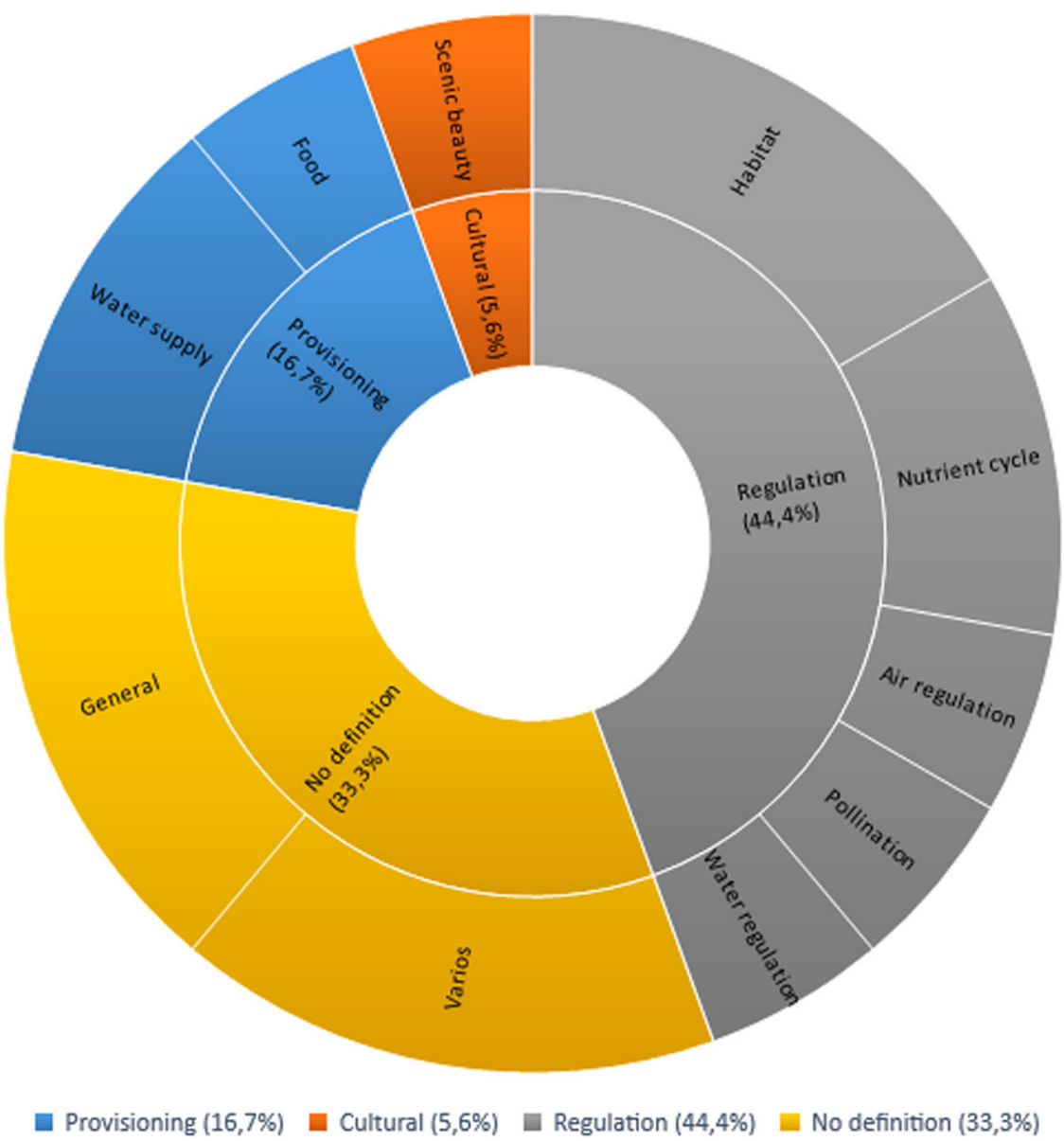



a. $\square$ Judge $₫$ Claimant $\square$ Defendant

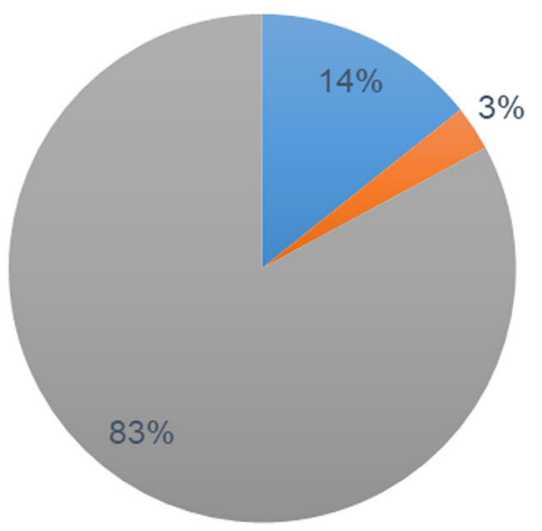

b. Indigenous People Afro None

\section{Colombian Constitutional Court Landmark Decision to Protect Arroyo Bruno and Environmental Rights of Wayúu Communities}

In the last level of results, we examine in detail Arroyo Bruno's case. This case deals with several substantial and procedural issues; however, for this article, we will cover only the relevant aspects related to the ES topics addressed in this judgment (Constitutional Court, SU-698/17, 2017).

The Wayúu people are an indigenous group based in the La Guajira desert. In this region lies the biggest open-pit coal mine in the world. In 2015, Wayúu leaders filed a rights based legal action (denominated Tutela) claiming that the project of diversion of Arroyo Bruno (Bruno River) to 
Table 1 Ecosystems, ecosystems services, and biodiversity providing contributions to the Wayúu indigenous communities in the area of the Arroyo Bruno

\begin{tabular}{llll}
\hline Ecosystems & Ecosystem services & & $\begin{array}{l}\text { Biodiversity } \\
\text { elements }\end{array}$ \\
\hline Streams & Supply (material) & Fisheries & Fater supply \\
& Cultural (no material) & Recreation & Water \\
& & Spiritual & Set of nature \\
& Supply and cultural & Medicinal uses and traditional & Roots and fruits \\
Tropical & ecological knowledge & \\
dry forest & Food and nutrition and traditional & Seems and fruits \\
& & ecological knowledge & \\
& Regulation & Microclimatic regulation & Shadow \\
& & Biological control for pastures & All forest \\
\hline
\end{tabular}

exploit the coal underneath threatened their constitutional rights to water, food security, and health, as well as the right to prior consultation and to develop and maintain their cultures. They sued governmental and environmental agencies, as well as "El Cerrejón", the company which operates the mine and whose property is shared by Anglo American, BHP, and Glencore corporations.

The plaintiffs were leaders of three different Wayúu communities, La Horqueta, La Gran Parada, and Paradero. They expressed that Arroyo Bruno had historically provided them with physical means to be adapted to the desert, like water, food sources, and medicinal plants. Also, the river was a crucial cultural and spiritual scenario for them. Given the lack of reliability of the environmental studies that supported the project, they asserted that Arroyo Bruno's deviation might bring the river disappearing and, consequently, the physical and cultural extinguishing of Wayúu people. They claimed for the project's suspension until they were allowed to participate in the decision-making process. They also demanded that the Colombian government carry out a comprehensive environmental impact assessment based on their dependence on land, water, and forest of the Arroyo Bruno to survive.

The courts of the first and second instances refused the lawsuit. Afterward, under a special procedure known as "Revisión" in the Colombian legal system, the Constitutional Court granted the petition. According to our research, this judgment is a landmark decision. For the first time in Latin America, a Court explicitly implemented the ES concept to safeguard human and environmental rights, particularly for the benefit of indigenous communities located in a vulnerable area to the climate crisis in Colombia: La Guajira.

La Guajira is a Colombian department located on the peninsula-which receives the same name-in the country's northeast region. Over $75 \%$ of La Guajira's area is desertified. Given the low precipitation levels, high solar radiation, elevated levels of evapotranspiration, and human activities - such as agriculture, overgrazing, and large-scale mining-freshwater is scarce. In this context, while surface water's vulnerability is high, Wayúu indigenous communities have developed extensive traditional ecological knowledge about the region's climate and other environmental processes since ancient times. Thanks to this ancient knowledge, they have adapted to the severe natural conditions of the desert. In the rural areas of La Guajira, where the Wayúu people are disseminated, there are no water and sewage systems. Thus, communities have built traditional water wells or water pans, using surface and groundwater runoff. Rivers are rare in this region. Lately, water shortage and reducing the availability of nutrients in the La Guajira desert has become a major public health problem. Consequently, local authorities have considered Arroyo Brunoas well as other freshwater sources-as strong potential to solve water problems in the area.

The Colombian Tribunal ascertained that indigenous communities depended highly upon the services that the Arroyo Bruno ecosystem provides (Table 1). The river has become the means, for example, to satisfy their rights to water, food security and sovereignty, and health. Through visits in loco, Wayúu people testimonies, and evidence collected, judges noted that Arroyo Bruno and its riparian area (tropical dry forest) provided many benefits to people. For example, besides the freshwater, the ecosystem contributes with roots and fruits to treat illnesses like flu and skin affectations; "mamón" seeds to produce fermented beverages; and edible fruits from "guáimaro" and "aceitunas" trees and "bocachico" fish as a food supply. Also, indigenous communities emphasized the other less visible but equally valuable benefits that Arroyo Bruno has given them. Since Wayúu are seminomadic peoples and exchange foodstuff with tribes in remote areas, they highlighted the importance of trees as providing shade and controlling temperature during their long walks and everyday life in the desert. As pastoralist communities, they also identified how crucial was forest to maintain grazing areas in the right conditions. 
In addition, under Wayúu's spiritual belief system, springs and rivers are essential sacred sites since they epitomize life's origin. Water is central to many Wayúu religious practices, including body, soul, and spiritual purification. Based on that, the Court conceded that Arroyo Bruno provides critical provisioning, supporting, and regulating services, as well as aesthetics, spiritual, and religious values to support Wayúu communities' life.

Furthermore, the Court realized that the Arroyo Bruno ecosystem was extremely fragile. First, its riparian forest (tropical dry forest) was at risk of disappearing. Only 10\% of this forest cover has remained in Colombia. Second, the ongoing climate crisis is exposing the ecosystem to greater and unprecedented stress. In addition, "El Cerrejón" has been developing large-scale mining activities since 1983. In recent years, to increase coal production from 35 to 41 million tons, the company has expanded the pit coal mine. This expansion process has required removing aquifers and soil, clearing forests, and deviating rivers, including the Arroyo Bruno.

According to the evidence, including the scientific opinion of the experts' panel designated by the Court, the Arroyo Bruno deviation project did not include other relevant variables that were critical to assess the environmental impact. In this already vulnerable environmental context, justices noted that the cumulative environmental effects of more than 30 years of large-scale mining activities in the region and the decreasing of nature's ability to recover were essential to understanding the environmental impacts of the Arroyo Bruno's deviation project. The Tribunal noted that there were many targeted projects within the whole coal mine-such as the Arroyo Bruno's one-and, over the years, environmental impact assessments had been carried out on these targeted projects but not on the whole mine. The Court disagreed with this piecemeal approach and called upon for a comprehensive one. In addition, the Tribunal called attention that the company had understood the river as a simple watercourse instead of a whole ecosystem. It explained why the project was focused on designing a water channel and not tackling how to recreate the conditions to maintain a healthy and functional ecosystem. This "isolation" approach overlooked the fact that the Arroyo Bruno landscape provided a wide range of ecosystem benefits to people. These depended on the interaction of the elements of the whole ecosystem. Thus, for environmental impact, the Court pointed out the project must ensure that deviation would not affect the ecosystem's functions.

Considering the prior elements, the Court pointed out, first, that the enjoyment of human rights for some communities depends directly and intimately on the biodiversity and the ESs it supports. Second, justices remarked that some ecosystems-strategic for human well-being-are subject to disproportionate environmental degradation and damage, which undermines their components and the ability to provide services. Based on this, the Colombian Tribunal ruled that when there is a high degree of biodiversity dependence by human communities and an increased vulnerability of ecosystems that they depend on, the government or private actors must safeguard the ecosystem to protect those rights from infringement.

Under the ESs based approach, the Constitutional Court stressed the urgency to protect the environment, particularly biodiversity, as a state policy and priority given its close and direct link with people's rights.

Based on the prior, the Court granted the petition and protected rights to water, food security, and the plaintiff communities' health. It urged for carrying out a comprehensive environmental impact assessment that included an ESs approach to overcome countless uncertainties around the effects of Arroyo Bruno's deviation. This assessment must also take into consideration Wayúu people's views and their participation. As part of this decision, the court ordered the establishment of an "interinstitutional roundtable" to address the issue, with the involvement of affected communities.

\section{Discussion}

Judicial decisions in Latin America have increasingly recognized the concept of ESs since 2012. This tendency has been most frequently used in Chile and Colombia, but other countries in the region have also explored and delved into this idea. This sheds light upon the path that is being paved for further analysis and study in the rest of the region. We suggest that the made progress by incorporating the ESs paradigm in Colombia and Chile is a product, to a certain extent, of the development of policies within their environmental institutions.

In the case of Chile, Environmental Tribunals created in 2012 by the 20.600 act, composed of lawyers and scientists specialized in environmental (Article 2, 20.600 act), have played a significant role in terms of access to justice, increasingly encouraging citizens to raise discussions on environmental matters. Interestingly, these tribunals have developed a consistent case law that links the ES paradigm with environmental damage. Environmental tribunals in Chile have established a rule in which the plaintiff is required to identify which ESs are being affected by the actions of the respondent as one of the ways to verify environmental damage. One might say this explains to a certain extent the increased use of this concept since 2016, as 10 of 16 of the judgments found in Chile have used the ES paradigm in cases related to environmental damage.

Likewise, since 2012, Colombia has relied on the National Policy for the Integral Management of 
Biodiversity and its ESs, which adopted the Millennium Ecosystem Assessment framework and promoted its implementation at several government agencies (Ministry of Environment and Sustainable Development, 2012). In addition, the implementation of ESs in judicial decisions has been promoted by the Constitutional Court's judicial activism, and most of the discussions around ESs have been brought by its judges, enforcing the protection of communities' human rights.

Nonetheless, the mentions of ESs in Latin America do not differ from what Sharon et al. (2018) found in their analysis of American and other common law legal systems, where the ESs are mostly mentioned peripherally in the judgments and are not central in court decisions. However, in Latin America, we found that judges are who use and incorporate the ES paradigm in their reasoning, rather than the plaintiffs. However, it is true that judges do not provide much conceptual development of the ES in their considerations.

It was no surprise to find that ES concepts are strongly associated with regulation services of rivers and coastal ecosystems in the judicial resolutions reviewed. Global Wetland Outlook (Ramsar 2018) found that the water quality of rivers in Latin America has declined, and the area of marine/coastal wetlands has decreased progressively close to $60 \%$. There are significant degradation processes under acceleration in Latin America, which has been documented in the latest global reports, including the aforementioned: regional assessment report on biodiversity and ESs for the Americas (Rice et al. 2018a, 2018b), Global Biodiversity Outlook 5 (Secretariat of the Convention on Biological Diversity 2020), and Living Planet Report 2020 (WWF 2020). In the face of governments' difficulties in curbing ecosystem degradation, civil society is turning to the courts to defend ecosystems. The ESs can provide judges with an analytical framework that aids them to resolve and decide in cases where connections between ecosystems' functioning and people's dependence on nature's contributions are well established (Millennium Ecosystem Assessment 2003).

In accordance with the aforementioned, it is clear that the use of ES has gained widespread recognition among Latin American courts. In this sense, the Colombian Constitutional Court decision to protect Arroyo Bruno and rights to water, food security, and health of Wayuú indigenous people has become a landmark ruling because of the following reasons:

First, the Court came up with this decision in a context with just $14 \%$ of the rulings related to ES involved ethnic communities. Although ethnic communities are more susceptible and are directly affected by the degradation of the ecosystems and climate change (Kronik and Verner 2010), it is bewildering that a tiny part of the judicial decisions involved these communities either as benefactors or actors of the rulings. In this setting, Arroyo Bruno's decision is groundbreaking.

Second, the Court brings the ES concept as a central mention, makes a conceptual development, and points out a classification of the services. Based on the National Policy for the Comprehensive Management of Biodiversity and its Ecosystemic Services, the Colombian Court defines ESs as "the wide range of benefits that biodiversity provides" (Constitutional Court of Colombia 2017a, 2017b). The justices asserted these contributions can be "direct and indirect, tangible, and less tangible, all of which must be taken into account in impact evaluation processes". Furthermore, the Court included the classification of ES in the judgment.

Provisioning services, the Court affirmed, consist of the set of goods and products that ecosystems provide to human beings to satisfy their needs, at different levels. These resources include, among others, biomass and water for nutrition, forest and nonforest products, genetic resources, and energy. These resources depend on the good conditions of the ecosystems, such as soil fertility, the supply of water resources, natural processes such as pollination, seed dispersal, natural control of pests and seeds, and stability in climatic conditions, among many others.

As a second set, the Court referred to regulation services as those which help to maintain air quality, control erosion, control diseases, and purify water. These are invisible services "that are shown on much broader time and space scales than the others, since they include processes such as primary production, soil formation, the provision of habitat for species, and the cycling of nutrients, among others" (Constitutional Court of Colombia 2017a, 2017b). The magistrates pointed out as examples of these services, "water regulation, carbon storage and capture, the treatment of waste, toxics, and other threats, the treatment and stabilization of mass flows, liquid and gaseous, such as the control of humidity, regulation and stabilization of atmospheric composition, climate, and temperature" (Constitutional Court of Colombia 2017a, 2017b). In addition, they highlighted that "despite the fact that these services are the basis and the condition of the other ESs, they have been underestimated and have not been studied in depth either" (Constitutional Court of Colombia 2017a, 2017b).

Furthermore, the Court incorporates the implications of culture in their classification. The Court refers to cultural services as those generated by the physical, spiritual, and symbolic interactions that are established between human communities and their environment. Consequently, "ecosystems make it possible to experience biodiversity, the elements and processes that comprise it, in areas such as scientific research, culture, education, religion, tourism, and entertainment" (Constitutional Court of Colombia 2017a, 2017b). 
Beyond the relevance of providing a conceptual framework of the ES paradigm and their classification, the Court recognized human well-being's dependence on biodiversity and based on it, translated the ES, a scientific concept, to the courtroom. In other words, justices used the ES concept as a tool to better understand the diversity and complex relations between Wayúu people and Arroyo Bruno's ecosystem and, ultimately, to establish the actual impact of the project for Wayúu communities and, at the same time, the scope of the protection granted for the Court.

According to the judgment, some anthropic activities such as the Arroyo Bruno's deviation project might deeply affect ecosystems and their ability to provide services to communities that depend highly on them. The effect of not protecting these services was to risk the water, food, and health of the communities - just to mention the most visible impacts - and, ultimately, to break the all links between people and the ecosystem that sustain their lives and livelihoods, as well as allow the perpetuation of their culture. The Tribunal reasoned that to protect their rights fully, it was necessary to preserve biodiversity and the services it provides. Consequently, the Court adopted an ESs approach to protect communities' rights.

One direct consequence of this ES approach was that the Court dismissed this assistance-based perspective, championed by some project supporters through which governmental or corporates assistance should take care of the communities' rights, for example, by supplying to communities through water trucks or offering feeding programs instead of maintaining the integrity of the ecosystem. This judicial reasoning entails some underpinning ideas worth it to highlight.

First, the relationship between Wayúu communities and the Arroyo Bruno is not limited by water for personal and domestic uses, such as drinking, sanitation, or food preparation. As the Court ascertained, these relationships are much more complex, encompassing ESs provided by the Arroyo and, in turn, contributing to the fulfillment of a whole range of human rights of the communities. The Tribunal recalled that beyond freshwater for drinking, the Arroyo Bruno ecosystem provides healthy and culturally appropriate food, regulates climate and soil erosion, and offers spiritual and recreational benefits for communities. In other words, this ES approach to protect human rights also integrates the cultural visions of the Wayúu people, meaning that for certain communities, many of nature's contributions are not entirely replaceable, and some are irreplaceable.

Second, in this case, the choice for an assistance-based approach would have fomented and deepened indigenous communities' dependency on public or corporate actors who provide the goods and services. This situation might accentuate the communities' inequality and marginalization, reduce their freedom of choice and action, and jeopardize their right to participation. Finally, justices explained that even if an assistance-based approach is considered as a possible path to fulfill human rights, in some cases-as the current one-the implementation of this approach brings fragmented and superficial solutions to problems with deep root causes. In this case, the Court observed that water scarcity and decreasing availability of nutrients in a desert such as La Guajira had been the origin of structural human rights violations for many Wayúu communities.

Finally, although the Court did not explicitly mention the idea of nature's contributions to people in the judgment, it does include this approach in the decision. By establishing an "interinstitutional roundtable" to carry out an environmental impact assessment to examine the effects of the Arroyo Bruno's deviation, the Court ruled that the roundtable must be comprised not only by governmental agencies, the mining company, or environmental experts but also by the Wayúu people. The involvement of affected communities in assessing the project's impacts recognized their knowledge system as equally legitimate to inform policies and decisions. The inclusiveness of the communities in this participatory space challenged the status quo in policymaking and decision-making about nature, dominated mainly by knowledge from the natural sciences and economics. This approach not only guarantees more legitimacy in the processes but also leads to better approaches to rights' protection since they are drawing from a much richer and broader information base.

Certainly, this is a promising way to incorporate ES concepts into the constitutional law sphere and ultimately flesh out environmental constitutionalism through innovative approaches to expand and deepen the rights of indigenous communities.

\section{Compliance with Ethical Standards}

Conflict of Interest The authors declare no competing interests.

Publisher's note Springer Nature remains neutral with regard to jurisdictional claims in published maps and institutional affiliations.

\section{References}

Administrative Tribunal of Costa Rica Section IV (2015) Ruling 79-2015. Administrative Tribunal of Costa Rica

Bonilla D (2012) Towards a constitutionalism of the Global South. Retrieved from: https://papers.ssrn.com/sol3/papers.cfm?abstra ct_id=2497585. Accessed 15 Nov 2020

Bonilla D (2019) Environmental radical constitutionalism and cultural diversity in Latin America: the rights of nature and buen vivir in Ecuador and Bolivia. Revista Derecho del Estado, Universidad Externado de Colombia, Bogotá D.C., p 3-23 
Boyd D (2012) The environmental rights revolution: a global study of constitutions, human rights, and the environment. UBC Press, Canada

Carvajal (2016) Extractivismo en América Latina. Fondo de Acción Urgente de América Latina, Bogotá D.C. Retrieved from: http:// fondoaccionurgente.org.co/site/assets/files/1175/extractivismo_ en_america_latina.pdf. Accesed 20 March 2021

Collins L (2017) Environmental constitutionalism in the Americas. In: Daly E, Kotze L, May J, Soyapi C (eds) New frontiers in environmental constitutionalism. United Nations Environment Programme, p. 138-145

Congressional Research Service (2020) Indigenous peoples in Latin America: statistical information. Congressional Research Service. https://fas.org/sgp/crs/row/R46225.pdf. Accessed 15 Nov 2020

CourtCases

Constitutional Court of Colombia (1992) Ruling T-415/92. Constitutional Court of Colombia

Constitutional Court of Colombia (1997) Ruling T-095/97. Constitutional Court of Colombia

Constitutional Court of Colombia (1995) Ruling T-220/95. Constitutional Court of Colombia

Constitutional Court of Colombia (2015a) Ruling C-094/2015. Constitutional Court of Colombia

Constitutional Court of Colombia (2015b) Ruling T-606 de 2015. Constitutional Court of Colombia

Constitutional Court of Colombia (2016a) Ruling T-730/2016. Constitutional Court of Colombia

Constitutional Court of Colombia (2017a) Ruling SU-698/2017. Constitutional Court of Colombia

Constitutional Court of Colombia (2017b) Ruling C-644/2017. Constitutional Court of Colombia

Constitutional Court of Colombia (2018) Ruling C-047/2018. Constitutional Court of Colombia

Constitutional Court of Colombia (2019a) Ruling C-369/2019. Constitutional Court of Colombia

Constitutional Court of Colombia (2019b) Ruling T-063/2019. Constitutional Court of Colombia

Constitutional Court of Colombia (2019c) Ruling T-196/2019. Constitutional Court of Colombia

Constitutional Court of Colombia (2016b) Ruling T-622/16. Constitutional Court of Colombia

Constitutional Court of Costa Rica (1993) Ruling 3705-93. Constitutional Court of Costa Rica

Constitutional Court of Hungary (1994) Ruling 28/1994. Constitutional Court of Hungary

Constitutional Court of Latvia (2009) Ruling 2008-38-03. Constitutional Court of Latvia

Daly E, Kotzé L, May J (2017) Introduction to environmental constitutionalism. In: Daly E, Kotze L, May J, Soyapi C (eds) New frontiers in environmental constitutionalism. United Nations Environment Programme, p. 30-33

Daly E, May J (2018) Implementing environmental constitutionalism. Widener University School of Law, Delaware. https://www.ca mbridge.org/core/books/implementing-environmental-constitutiona lism/BABAA1DC62FA0D222DB015D9E9EB8381. Accessed 26 April 2021

Díaz S, Settele J, Brondízio ES et al. (2019) Summary for policymakers of the global assessment report on biodiversity and ecosystem services of the Intergovernmental Science-Policy Platform on Biodiversity and Ecosystem Services. IPBES secretariat, Bonn, Germany, https://doi.org/10.5281/zenodo. 3553579

First Chamber of Appeal of La Plata Argentina (2006) Ruling 232.609. First Chamber of Appeal of La Plata Argentina

Gomez-Betancur L (2020) The rights of nature in the Colombian Amazon: examining challenges and opportunities in a transitional justice setting. UCLA J Int Law Foreign Affairs 25(1). Retrieved from https://escholarship.org/uc/item/5bk379rd. Accessed 20 March 2021

Iacovino A (2020) Constitucionalismo ecológico en América Latina: de los derechos ambientales a los derechos de la naturaleza. Cult Latinoam 31(1):266-320. https://doi.org/10.14718/CulturaLa tinoam.2020.31.1.12

IPBES (2017) Update on the classification of nature's contributions to people by the Intergovernmental Science-Policy Platform on Biodiversity and Ecosystem Services. IPBES. https://ipbes.net/ sites/default/files/downloads/pdf/ipbes-5-inf-24.pdf. Accessed Nov 302020

Kronik J, Verner D (2010) Indigenous peoples and climate change in Latin America and the Caribbean. The International Bank for Reconstruction and Development, Washington, DC

May J, Daly E (2009) Vindicating fundamental environmental rights: judicial acceptance of constitutionally entrenched environmental rights. In: Widener Law School Legal Studies Research Paper Series no. 09-35. p. 373-437. Widener University School of Law, Delaware. https://doi.org/10.2139/ssrn.1479849

May J, Daly E (2014) Global environmental constitutionalism. Cambridge University Press. https://doi.org/10.1017/CBO9781139135559

May J, Daly E (2017) Judicial handbook on environmental constitutionalism. United Nations Environment Programme. https://w edocs.unep.org/bitstream/handle/20.500.11822/20766/judicial-ha ndbook-environmental-constitutionalism.pdf?sequence $=$ 3\&isAllowed $=\mathrm{y}$ Accessed 30 Nov 2020

May J, Daly E (2019) Judicial handbook on environmental constitutionalism. United Nations Environment Programme. https://www.unep.org/resources/publication/global-judicial-ha nbook-environmental-constitutionalism-third-edition Accessed 30 November 2020

Millennium Ecosystem Assessment (2003) Ecosystems and human well-being: a framework for assessment. Island Press, Washington, DC

Ministerio de Ambiente y Desarrollo Sostenible (2012) Política nacional para la gestión integral de la biodiversidad y sus servicios ecosistémicos (PNGIBSE). Ministerio de Ambiente y Desarrollo Sostenible, Instituto de Investigación de Recursos Biológicos Alexander von Humboldt, Bogotá, DC

Ramsar (2018) Global wetland outlook: state of the world's wetlands and their services to people. Ramsar Convention Secretariat, Gland, Switzerland

Rice J, Seixas CS, Zaccagnini ME et al. (2018a) Summary for policymakers of the regional assessment report on biodiversity and ecosystem services for the Americas of the Intergovernmental Science-Policy Platform on Biodiversity and Ecosystem Services. Bonn, Germany. https://ipbes.net/sites/default/files/spm_america s_2018_digital.pdf. Accessed 30 Nov 2020

Rice J, Seixas CS, Zaccagnini ME et al. (2018b) The IPBES regional assessment report on biodiversity and ecosystem services for the Americas. Secretariat of the Intergovernmental Science-Policy Platform on Biodiversity and Ecosystem Services, Bonn, Germany

Secretariat of the Convention on Biological Diversity (2020) Global Biodiversity Outlook 5. Secretariat of the Convention on Biological Diversity, Montreal

Second Environmental Tribunal of Chile (2014) Ruling R 40-2014. Second Environmental Tribunal of Chile

Setzer J, Benjamin L (2020) Climate litigation in the Global South: constraints and innovations. London School of Economics and Political Science, Cambridge University Press, London, https:// doi.org/10.1017/S2047102519000268

Sharon O, Fishman N, Ruhl J et al. (2018) Ecosystem services and judge-made law: a review of legal cases in common law countries. Elsevier B.V, USA 
State Council of Colombia (2012) Ruling 85001-23-31-001-201200044-00. State Council of Colombia

State Council of Colombia (2020a) Ruling 25000-23-24-000-201200078-01 (AP). State Council of Colombia

State Council of Colombia (2020b) Ruling 15001-23-33-000-201300354-02(AP). State Council of Colombia

State Council of Colombia (2020c) Ruling 15001-23-33-000-201400223-02(AP). State Council of Colombia

Supreme Court of India (1991) Subhash Kumar vs. State Of Bihar And Or. Supreme Court of India

Supreme Court of Justice of Argentina (2014) Ruling V. 67 XLVI. Supreme Court of Justice of Argentina

Supreme Court of Justice of Argentina (2019) Ruling CSJ 85/2006. Supreme Court of Justice of Argentina

Supreme Court of Justice of Argentina (2020) Ruling CSJ 243/2014. Supreme Court of Justice of Argentina

Supreme Court of Justice of Chile, Constitutional Chamber (2019) Ruling 1239-2018. Supreme Court of Justice of Chile, Constitutional Chamber

Supreme Court of Justice of Costa Rica, Constitutional Chamber (2019) Ruling 2019004046. Supreme Court of Justice of Costa Rica, Constitutional Chamber

Supreme Court of Justice of Costa Rica, Constitutional Chamber (2020) Ruling 2020015548. Supreme Court of Justice of Costa Rica, Constitutional Chamber

Supreme Court of Justice of México (2016) Ruling R. 840/2016. Supreme Court of Justice of México

Supreme Court of Justice of México (2017) Ruling 2a/J.19/2017. Supreme Court of Justice of México

Supreme Court of Nepal (2016) Advocate Prakash Mani Sharma and others v. Godavari Marble Industries Pvt. Ltd. and others. Supreme Court of Nepal

Supreme Court of Philippines (1993) Juan Antonio Oposa et al. v. The Honorable Fulgencio S. Factoran, Jr G.R. No. 101083, 224 S.C. R.A. 792. Supreme Court of Philippines

Supreme Court of Chile (1998) Comunidad de Chanaral v. Codeco División el Saldor. Supreme Court of Chile

Svampa M (2012) Consenso de los commodities, giro ecoterritorial y pensamiento crítico en América Latina. In: Oliver L (ed) Movimientos socioambientales en América Latina. Observatorio Social de América Latina (OSAL), Argentina. p. 16-35. http:// biblioteca.clacso.edu.ar/clacso/osal/20120927103642/OSAL32. pdf. Accessed April 272021
Third Constitutional Tribunal of Dominican Republic (2013) Ruling 2019004046. Third Constitutional Tribunal of Dominican Republic

Third Environmental Tribunal of Chile (2016a) Ruling D 3-2014. Third Environmental Tribunal of Chile

Third Environmental Tribunal of Chile (2016b) Ruling R 25-2016. Third Environmental Tribunal of Chile

Third Environmental Tribunal of Chile (2017a) Ruling S 16-2017. Third Environmental Tribunal of Chile

Third Environmental Tribunal of Chile (2017b) Ruling D 17-2016. Third Environmental Tribunal of Chile

Third Environmental Tribunal of Chile (2018a) Ruling D 23-2016. Third Environmental Tribunal of Chile

Third Environmental Tribunal of Chile (2018b) Ruling D 11-2015. Third Environmental Tribunal of Chile

Third Environmental Tribunal of Chile (2018c) Ruling D 7-2015. Third Environmental Tribunal of Chile

Third Environmental Tribunal of Chile (2018d) Ruling R 42-2016. Third Environmental Tribunal of Chile

Third Environmental Tribunal of Chile (2019a) Ruling D 20-2016. Third Environmental Tribunal of Chile

Third Environmental Tribunal of Chile (2019b) Ruling D 21-2016. Third Environmental Tribunal of Chile

Third Environmental Tribunal of Chile (2019c) Ruling D 30-2017. Third Environmental Tribunal of Chile

Third Environmental Tribunal of Chile (2020) Ruling D 6-2019. Third Environmental Tribunal of Chile (2020)

UNEP-WCMC (2016) The state of biodiversity in Latin America and the Caribbean: a mid-term review of progress towards the Aichi Biodiversity Targets. UNEP-WCMC, Cambridge, UK. https://www.cbd.int/gbo/gbo4/outlook-grulac-en.pdf. Accessed 30 Nov 2020

UN General Assembly (2014) Harmony with nature report of the secretary-general. UN General Assembly. https://undocs.org/ pdf?symbol=en/A/69/322 Accessed 30 Nov 2020

UN General Assembly (2017) Report of the special rapporteur on the issue of human rights obligations relating to the enjoyment of a safe, clean, healthy and sustainable environment. UN General Assembly. https://documents-dds-ny.un.org/doc/UNDOC/GEN/ G17/009/97/PDF/G1700997.pdf?OpenElement. Accessed 30 Nov 2020

WWF (2020) Living Planet Report 2020-bending the curve of biodiversity loss. WWF, Gland, Switzerland 